\title{
Neuronal Acetylcholine Receptor Subunit Alpha-5
}

National Cancer Institute

\section{Source}

National Cancer Institute. Neuronal Acetylcholine Receptor Subunit Alpha-5. NCI

Thesaurus. Code C77127.

Neuronal acetylcholine receptor subunit alpha-5 (468 aa, $\sim 53 \mathrm{kDa}$ ) is encoded by the human CHRNA5 gene. This protein plays a role in ion transport. 